GU J Sci, Part C, 5(4): 71-85 (2017)

Gazi Üniversitesi
Fen Bilimleri Dergisi
PART C: TASARIM VE TEKNOLOJI
dergipark.gov.tr/http-gujsc-gazi-edu-tr

\title{
İl Bazında Enerji Dengesi Analizi: Karabük Örneği
}

\author{
Seyfi ŞEVIK* \\ Hitit Üniversitesi, Teknik Bilimler Meslek Yüksekokulu Elektrik ve Enerji Bölümü, 19169, Çorum,
}

Öz

Makale Bilgisi

Başvuru: 20/03/2017

Düzeltme: 25/07/2017

Kabul: 20/09/2017

\section{Anahtar Kelimeler \\ Enerji dengesi, \\ Elektrik, enerji akıs \\ şemasl, Karabük}

\section{Keywords}

Energy balance,

electricity, energy

flowchart, Karabük
Bu çalışmanın amacı; Karabük ilinin enerji arz-talep dengesini ortaya koymak, bu denge içerisinde kahverengi ve yeşil enerjilerin payını ve bunların genel eğilimini değerlendirmek ve bir enerji akış şeması oluşturmaktır. Karabük ilinde, kurulu gücü $122 \mathrm{MW}$ olan 4 adet lisanslı ve 1 adet lisanssız olmak üzere toplamda 5 adet aktif elektrik enerji santrali ile y1llık yaklaşı $530 \mathrm{GWh}$ elektrik üretimi yapılmaktadır. Bu üretim ile, kendi elektrik tüketiminin \% 45'i karşılanabilmektedir. Karabük ili elektrik kurulu gücünün Türkiye kurulu gücüne oranı $\% 0.17$ iken Türkiye tüketimine oran1 \% 0.21 'dir. Yenilenebilir enerjinin toplam kurulu güç içerisindeki payı \% 58.8 iken toplam enerji üretimi içerisindeki payı ise \% 32'dir. Karabük, yeterli enerji kaynaklarına sahip olmayıp bununla birlikte, fosil yakıt tüketimi de oldukça yüksektir. Karabük, yerli olmayan enerji kaynaklarının ağır bir sömürüsü ile karşı karşıyadır. Yenilenebilir enerji ve etkili enerji verimliliği programları, yerli olmayan enerji kaynakları üzerindeki ülkenin bağımlılığını azaltabilir

\section{Provincial Energy Balance Analysis: Karabük Sample}

\begin{abstract}
The purpose of this study; to reveal the energy supply-demand balance of the Karabük province, to evaluate their overall trends and the share of brown and green energy in the balance and to create an energy flowchart. Karabük province has an installed capacity of 122 MW with 4 licensed and 1 unlicensed power plants. It is carried out about $530 \mathrm{GWh}$ of electricity generation annually. With this generation, $45 \%$ of own electricity consumption can be met. Ratio of Karabük electricity installed capacity to installed capacity of Turkey is $0.17 \%$, it's ratio is $0.21 \%$ to consumption in Turkey. While share in the total installed capacity of renewable energy is $58.8 \%$, the share in total energy generation is $32 \%$. Karabük haven't energy resources however, fossil fuel consumption is also very high. Province of Karabük is characterized by a heavy exploitation of non-domestic energy resources. Karabük does not have sufficient energy sources. Effective energy efficiency programs and renewable energy can reduce country's reliance on non-domestic energy sources.
\end{abstract}

\section{GİRIŞ̧ (INTRODUCTION)}

Günümüz dünyasında enerji, su kadar vazgeçilmez bir ürün haline gelmiştir. Enerjiyi yönetmek ve sürdürülebilir bir konuma getirmek de bir o kadar önemlidir. Dünya, yenilenebilir enerji ve enerji verimliliği teknolojileri konusunda büyük gelişmeler gerçekleştirirken, Türkiye bu gelişmeleri izleyen ve bazı eğitim-tanıtım kapsamlı projeler yürüten bir konumdan, şimdilerde, enerji bağımlılığını azaltmak ve iklim değişikliği sorununu çözmek için tüm dünyada olduğu gibi yenilenebilir enerji alanında uygulamaya dönük projeler üretmektedir.

Enerji denildiğinde ilk akla gelen enerji kaynakları ve elektriktir. Elektrik, ülke bazında ele alındığında kurulu güç, puant, emre amade, üretim ve tüketim konuları ön plana çıkmaktadır. Bunun beraberinde elektriğin iletim ve dağıtımı gelmektedir. Türkiye'de elektrik iletim sistemi (gerilim seviyeleri $66 \mathrm{kV}, 154 \mathrm{kV}$ ve $400 \mathrm{kV}$ ) ve dağıtım sistemi illerin coğrafik sınırlarına göre oluşturulmamakla birlikte, elektrik üretim tesisleri coğrafik konumlarına göre illerin coğrafik sınırları içerisinde yer aldığı kabul edilebilir ve ayrıca yüksek gerilim seviyesinde elektrik iletim tesisleri illere göre ayrılabilir [1]. Elektrik üretimi kurulu kapasitesi, iletim ve dağıtım şebekesi kapasitesi ve kaynaklar gibi kavramlar ülke genelinde ele alınmaktadır. Günümüz şartlarında, 
bölgesel veya il bazında ele alınması mümkün değildir. Buna karşın, Çin'in enerji sorunlarını çözmesi, il düzeyinde enerji ile ilgili politikaların etkin bir şekilde uygulanmış olmasına bağlanmaktadır [2]. Ayrıca son zamanlarda enerji analizi konusunda, bölgesel [3] ve il bazında [1, 2, 4-6] bazı çalışmalar yapılmaktadır. Bastianoni ve arkadaşları (2002), Ravenna (İtalya) ve ilçelerinin (Ravenna, Faenza ve Lugo) bir termodinamik analizini ve sera gazlarının denge bazlı entropi atık üretiminin bir değerlendirmesini yapmışlar ve enerji sektörünün toplam sera gazı üretiminin \% 92'sinden sorumlu olduğunu belirtmişlerdir [4]. Liu ve arkadaşları (2008), Liaoning ili için ekolojikekonomik sistemin emerji (Bir ürünün yaşam döngüsünde kullandığı toplam enerji) analizini yapmışlar ve Liaoning ilinde yenilenebilir olmayan kaynakların toplam tüketilen enerjinin \% 74'ünü oluşturduğunu belirtmişlerdir [5]. Türkiye'de de benzer çalışmalar yapılmıştır. Ankara [1], İstanbul (Anadolu Yakası), Kocaeli ve Bursa [6] gibi iller için elektrik üretim-tüketim durumu analizleri yapılmıştır.

Enerji kaynaklarını ve onların nihai kullanımını daha iyi anlayabilmek için karmaşık ilişkileri görselleştiren akış diyagramları oluşturulur [7]. Lawrence Livermore Ulusal Laboratuarı (LLNL) tarafından 1970'lerin başından beri başta Livermore olmak üzere ABD enerji akış şemaları (Sankey diyagramları) yayınlanmaktadır [8]. Mischke ve Xiong (2014), Çin enerji sisteminin bölgesel karakteristiklerini daha kolay anlayabilmek için üç farklı bölgenin enerji sankey diyagramlarını oluşturmuşlardır [3]. Zhang ve Wang (2012), Jiangsu ili için enerji akış kartı oluşturmuşlar ve diğer bölgelerden ithal edilen enerjinin toplam birincil enerji arzında \% 96.1'lik kısmı oluşturduğunu ve enerji arzının ağırlıklı olarak kömür olduğunu belirtmişlerdir [9]. Yang ve arkadaşları (2013), Qinghai ili için ekonomi ve enerji sistemi çerçevesinde Qinghai ilinin enerji gelişimi üzerinde sistem dinamik modelini oluşturmuşlar ve enerji talebinin 2015 yılında \% 90.37 oranında artacağını belirtmişlerdir [2]. Cheng ve ark. (2016), Çin'in Guangdong ili için 2020 yılına kadar enerji ve karbon emisyon hedefleri üzerinde, güç sektöründeki düşük karbon politikasının etkilerini yedi senaryo ile analiz etmişlerdir. Onlar, Guangdong ili için düşük karbon politikası uygulanmasıyla dışarıdan alınan kömür ve petrol üzerinde enerji güvenliğinde bir iyileşme gerçekleştirileceğini ve Guangdong ilinin kömür tüketimi 2017-2019 yılları arasında zirve yapabileceğini ifade etmişlerdir. [10].

$\mathrm{Bu}$ çalışmada ise Karabük ili, enerji açısından ele alınmakta ve enerji dengesi ortaya konulmaktadır. $\mathrm{Bu}$ denge içerisinde kahverengi ve yeşil enerjilerin payı ve bunların genel eğilimi değerlendirilmekte ve bir enerji akış şeması oluşturulmaktadır. Oluşturulan enerji akış şeması, ilin enerji açısından daha iyi anlaşılabilmesine ve geniş kitlelere yönelik analiz imkanı sunmasına yardımcı olacaktır. $\mathrm{Bu}$ çalışma; enerji, ekonomi, çevre, verimlilik ve sürdürülebilir kalkınmayı yeterince sağlayabilmek için gerekli imkanların bir kısmını açık bir şekilde sunmayı amaçlamaktadır.

\section{METODOLOJİ (METHODOLOGY)}

Bu çalışma; a) yük tevzi, bölgesel kapasite, il bazlı, çevresel ve şirket raporları, b) istatistiksel ve seçilmiş göstergeler ve c) araştırma çalışmalarından yararlanarak ham veya ayıklanmış veriler bir bütün olarak ele alınıp işlenerek oluşturulmuştur. Verilerin bazılarının ortak olmasına karşın farklılık gösterenler doğrulanarak eklenmiştir. İl bazında yeterli veri oluşturulmamış olması bir kısım verilerin ve doğruluğunun tespit edilememiş olması nedeniyle bazı veriler kullanılamamıştır. Karabük ilinin analizinden önce Türkiye'nin sadece elektrik üretim ve tüketim verilerinin verilmesi bu çalışma için yeterli kabul edilmiştir.

\section{BULGULAR VE TARTIŞMA (RESULTS AND DISCUSSION)}

\subsection{Türkiye Elektrik Üretimi ve Tüketimi (Turkey Electricity Generation and Consumption)}

TEİAŞ verilerine göre; 31 Mart 2016 itibariyle 1666 adet santral ile Türkiye'nin elektrik kurulu gücü 74039 MW'tır. 2015 yılı Türkiye kurulu gücünün kaynaklara göre dağılımı Şekil 1'de gösterilmiştir [12]. Kurulu güç içerisinde başı çeken kaynakların hidrolik, doğalgaz ve kömür olduğu görülmektedir. Doğalgaza "diğer 2"de yer alan dilim de eklendiğinde doğalgaz ile hidrolik eşit 
duruma gelmekle birlikte fosil yakıtların üstünlügü devam etmektedir. Öte yandan, yenilenebilir enerjiler de artık pasta dilimlerinde görünür hale gelmiştir. Dünya genelinde olduğu gibi Türkiye'de de yenilenebilir enerjiye olan ilgi son yıllarda hızlı bir artış göstermiştir. Öyle ki, Lisanssız Elektrik Üretim Yönetmeliği kapsamında 28 Mayıs 2015 tarihi itibarı ile toplam başvuru sayısı 8566 adet olup toplam başvuru içinde GES başvurularının payı ise \% 85+'dır [11].

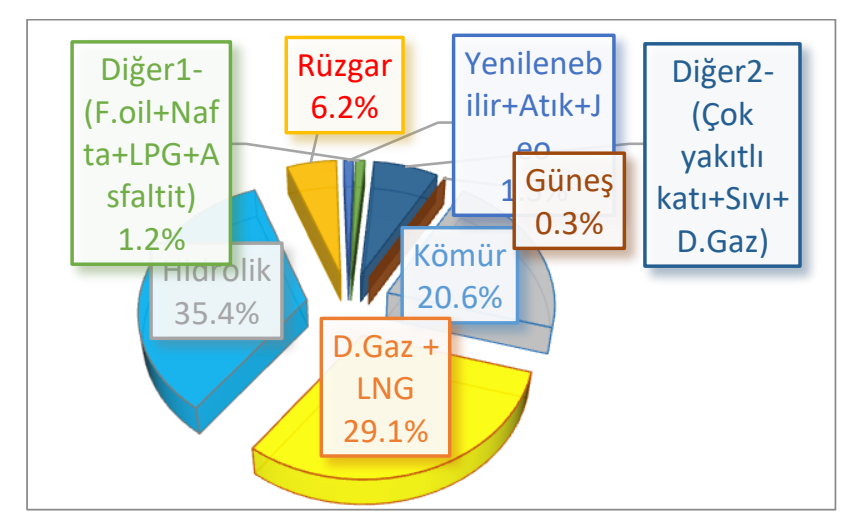

Şekil 1. 2015 yılı Türkiye kurulu gücün kaynaklara göre dağglımı [12].

(Turkey's installed power distribution according to sources in 2015).

31 Ocak 2016 itibariyle bölgelere göre, elektrik üretim-tüketim ve kurulu güç verileri ise Tablo 1'de gösterilmiştir. Tabloya göre en fazla elektrik kurulu gücü, üretimi ve tüketimi Marmara Bölgesinde, en düşük kurulu kapasite ve en az üretim Doğu Anadolu Bölgesinde gerçekleştirilirken, üretimin tüketimi karşılama oranının en yüksek olduğu yerler ise sırasıyla Karadeniz ve Ege Bölgeleri olarak görülmektedir. Üretim-tüketim dengesi açısından bakıldığında Marmara Bölgesi dengede olan bir bölge olduğu görülmektedir. Üretim-tüketim oranı açısından değerlendirildiğinde \% 220 ile Karadeniz Bölgesi ve \% 158 ile Ege Bölgesi öne çıkmaktadır. Doğalgaz santralleri yüksek elektrik tüketimi olan bölgelerde, yerli kömür santralleri kömür madeni bulunan bölgelerde, ithal kömür santralleri kıyı şehirlerinde, HES'ler Fırat-Dicle havzası ile Çoruh havzasında, RES'ler Ege kıyıları ile Akdeniz'in doğusunda, GES'ler ise güney bölgelerde kümelenmektedir.

Tablo 1. 31 Ocak 2016 itibariyle bölgelere göre bazı elektrik verileri [13].

\begin{tabular}{lllll}
\multicolumn{5}{c}{ (Some electrical data by region as of January 31, 2016). } \\
\hline No BÖLGE & KG (MW) & YÜ (GWh) & ÜTO (\%) \\
\hline 1 & Karadeniz Bölgesi & 11704 & 42832 & 220 \\
2 & Akdeniz Bölgesi & 15058 & 50557 & 129 \\
3 & Ege Bölgesi & 11801 & 60923 & 158 \\
4 & Doğu Anadolu Bölgesi & 4320 & 13329 & 120 \\
5 & Marmara Bölgesi & 18228 & 87402 & 93 \\
6 & Güneydoğu Anadolu Bölgesi & 7437 & 25388 & 86 \\
7 & İç Anadolu Bölgesi & 4751 & 20216 & 63 \\
\hline KG: Kurulu güç, YÜ: Yaklaşı üretim, ÜTO: Üretim/tüketim oranı & \multicolumn{5}{l}{} \\
\hline \multicolumn{5}{l}{}
\end{tabular}

31 Ocak 2016 itibariyle illere göre elektrik santrali kurulu güç, ortalama elektrik üretim miktarı ve il elektrik tüketimi karşılama oranları Tablo 2'de gösterilmiştir. Kurulu güç bakımından en yüksek kapasiteye sahip olan il Kahramanmaraş, en düşük kapasiteli il ise Kilis'dir. Karabük ilinin enerji arz-talep dengesi, diğer iller ile kıyaslandığında çok kötü bir durumda olmamakla birlikte bölgesinde oldukça kötü bir durumdadır. KG, YÜ ve ÜTO değerlerinin tümünde Türkiye ortalamasın altında değerlere sahip olduğu görülmektedir.

Tablo 2. 31 Ocak 2016 itibariyle şehirlere göre bazı elektrik verileri [13'ten uyarlanmıştır]. 
(Some electrical data by provinces as of January 31, 2016 [Adapted from 13])

\begin{tabular}{|c|c|c|c|c|c|c|c|c|c|}
\hline No & İL & $\begin{array}{l}\text { KG } \\
(\mathrm{MW})\end{array}$ & $\begin{array}{l}\text { YÜ } \\
(\mathrm{GWh})\end{array}$ & $\begin{array}{l}\begin{array}{l}\text { ÜTO } \\
(\%)\end{array} \\
\end{array}$ & No & İL & KG (MW) & $\begin{array}{l}\text { YÜ } \\
(\mathrm{GWh})\end{array}$ & ÜTO (\%) \\
\hline 1 & Kahramanmaraş & 4160 & 5712 & 109 & 42 & Siirt & 344 & 783 & 101 \\
\hline 2 & İzmir & 3993 & 23149 & 111 & 43 & Rize & 316 & 919 & 100 \\
\hline 3 & Şanlıurfa & 3422 & 10691 & 148 & 44 & Erzincan & 306 & 885 & 271 \\
\hline 4 & Adana & 3376 & 15830 & 215 & 45 & Kırşehir & 290 & 484 & 96 \\
\hline 5 & Samsun & 3262 & 15475 & 474 & 46 & Afyonkarahisar & 281 & 1209 & 82 \\
\hline 6 & İstanbul & 3001 & 6143 & 14 & 47 & Ordu & 254 & 510 & 38 \\
\hline 7 & Bursa & 2782 & 9710 & 77 & 48 & Bilecik & 235 & 1238 & 74 \\
\hline 8 & Hatay & 2684 & 12509 & 154 & 49 & Adiyaman & 229 & 600 & 46 \\
\hline 9 & Sakarya & 2421 & 17159 & 580 & 50 & Bingöl & 215 & 559 & 219 \\
\hline 10 & Çanakkale & 2270 & 14148 & 306 & 51 & Konya & 213 & 478 & 8 \\
\hline 11 & Diyarbakır & 2251 & 7507 & 136 & 52 & Amasya & 189 & 461 & 72 \\
\hline 12 & Elazığ & 2237 & 8047 & 511 & 53 & Muş & 175 & 413 & 76 \\
\hline 13 & Kocaeli & 2153 & 14178 & 95 & 54 & Ardahan & 161 & 466 & 422 \\
\hline 14 & Antalya & 2087 & 7731 & 101 & 55 & Yalova & 158 & 1083 & 114 \\
\hline 15 & Muğla & 2055 & 8768 & 274 & 56 & Kars & 157 & 290 & 67 \\
\hline 16 & Manisa & 1996 & 8465 & 202 & 57 & Kırıkkale & 135 & 510 & 65 \\
\hline 17 & Ankara & 1944 & 10909 & 81 & 58 & Karabük & 122 & 530 & 45 \\
\hline 18 & Zonguldak & 1925 & 11910 & 340 & 59 & Isparta & 111 & 192 & 16 \\
\hline 19 & Balıkesir & 1896 & 10332 & 299 & 60 & Burdur & 110 & 301 & 29 \\
\hline 20 & Artvin & 1699 & 4155 & 1055 & 61 & Tunceli & 107 & 271 & 238 \\
\hline 21 & Tekirdağ & 1617 & 9714 & 173 & 62 & Nevşehir & 106 & 308 & 40 \\
\hline 22 & Kurklareli & 1609 & 3462 & 117 & 63 & Düzce & 99 & 263 & 25 \\
\hline 23 & Denizli & 1422 & 9431 & 270 & 64 & Edirne & 84 & 236 & 17 \\
\hline 24 & Kütahya & 1110 & 5925 & 367 & 65 & Uşak & 82 & 320 & 25 \\
\hline 25 & Osmaniye & 1004 & 3084 & 95 & 66 & Malatya & 67 & 206 & 12 \\
\hline 26 & Mersin & 981 & 3727 & 77 & 67 & Van & 67 & 291 & 14 \\
\hline 27 & Sivas & 905 & 3347 & 180 & 68 & Mardin & 55 & 111 & 2 \\
\hline 28 & Aydın & 862 & 3657 & 144 & 69 & Kastamonu & 54 & 145 & 17 \\
\hline 29 & Giresun & 796 & 1699 & 244 & 70 & Batman & 52 & 192 & 11 \\
\hline 30 & Erzurum & 755 & 1707 & 128 & 71 & Hakkari & 49 & 128 & 17 \\
\hline 31 & Gümüşhane & 623 & 1241 & 565 & 72 & Niğde & 38 & 99 & 10 \\
\hline 32 & Şırnak & 602 & 3954 & 233 & 73 & Bayburt & 26 & 69 & 53 \\
\hline 33 & Trabzon & 577 & 1340 & 96 & 74 & Yozgat & 25 & 49 & 6 \\
\hline 34 & Eskişehir & 558 & 2217 & 85 & 75 & Aksaray & 24 & 138 & 22 \\
\hline 35 & Karaman & 544 & 1471 & 318 & 76 & Iğdır & 14 & 50 & 25 \\
\hline 36 & Sinop & 543 & 872 & 202 & 77 & Ağn1 & 10 & 12 & 1 \\
\hline 37 & Kayseri & 509 & 1673 & 49 & 78 & Bartın & 8 & 14 & 4 \\
\hline 38 & Gaziantep & 475 & 1541 & 26 & 79 & Kilis & 7 & 10 & 5 \\
\hline 39 & Tokat & 446 & 1525 & 155 & 80 & Çankırı & 3 & 3 & 0.85 \\
\hline 40 & Bolu & 410 & 691 & 62 & 81 & Bitlis & 1 & 3 & 0.39 \\
\hline 41 & Çorum & 355 & 1011 & 104 & \multicolumn{2}{|c|}{$\begin{array}{l}\text { Ort. göre Karabük } \\
\text { Maks. göre Karabük }\end{array}$} & $\begin{array}{l}-642 \% \\
-3310 \%\end{array}$ & $\begin{array}{l}-600 \% \\
-4268 \%\end{array}$ & $\begin{array}{l}-214 \% \\
-2244 \%\end{array}$ \\
\hline
\end{tabular}


KG, YÜ ve ÜTO değerlerinin hem ortalama hem de en yüksek değerlere göre yüzdelik fark hesapları yapılmıştır. Bu değerler \% -214 ile \% -4268 değerleri arasında elde edilmiştir. Örneğin Karabük, ortalama ÜTO değerine uzaklığı \% -214 gibi çok da görece sıkıntılı olmayan bir değere sahipken YÜ değeri açısından incelendiğinde bu değerin maksimum değere uzaklığı \% -4268 olarak görünmektedir.

Karabük, Türkiye'nin kuzeyinde Karadeniz Bölgesi'nde yer alan ve $41^{\circ} 13^{\prime} \mathrm{K}$ enlem, $32^{\circ} 37^{\prime} \mathrm{D}$ boylam ve 485 m yükseltidedir. Karabük, Merkez ilçesi ile beraber 6 ilçe, 2 belde ve 270 köye sahip olup nüfusu 237 bin'dir. Karabük, 101617 km elektrik dağıtım şebekesi uzunluğuna sahip olan Başkent EDAŞ bölgesinde yer almaktadır. 2014 yılı Nisan ayı itibari ile Başkent EDAŞ bölgesindeki kurulu güç 4055.65 MW olup, bölgedeki santrallerin yakıt tipine göre dağılımı Şekil 2'de verilmiştir. Görüldüğ̈ üzere bölgedeki santraller kömür ağırlıklı olup hatta yaklaşı \% 90 ile büyük bir bölümünü kömür ve doğalgaz oluşturmaktadır. Başkent EDAŞ için yapılan yeni başvuru miktarı ise 6861 MW'tır [14]. Başvurusu yapılan santrallerin yakıt tipine göre dağılımı Şekil 3'te verilmiştir. Yine burada da başvuruların büyük çoğunluğunun doğalgaz ve kömür santrallerine yapıldığı görülmektedir.

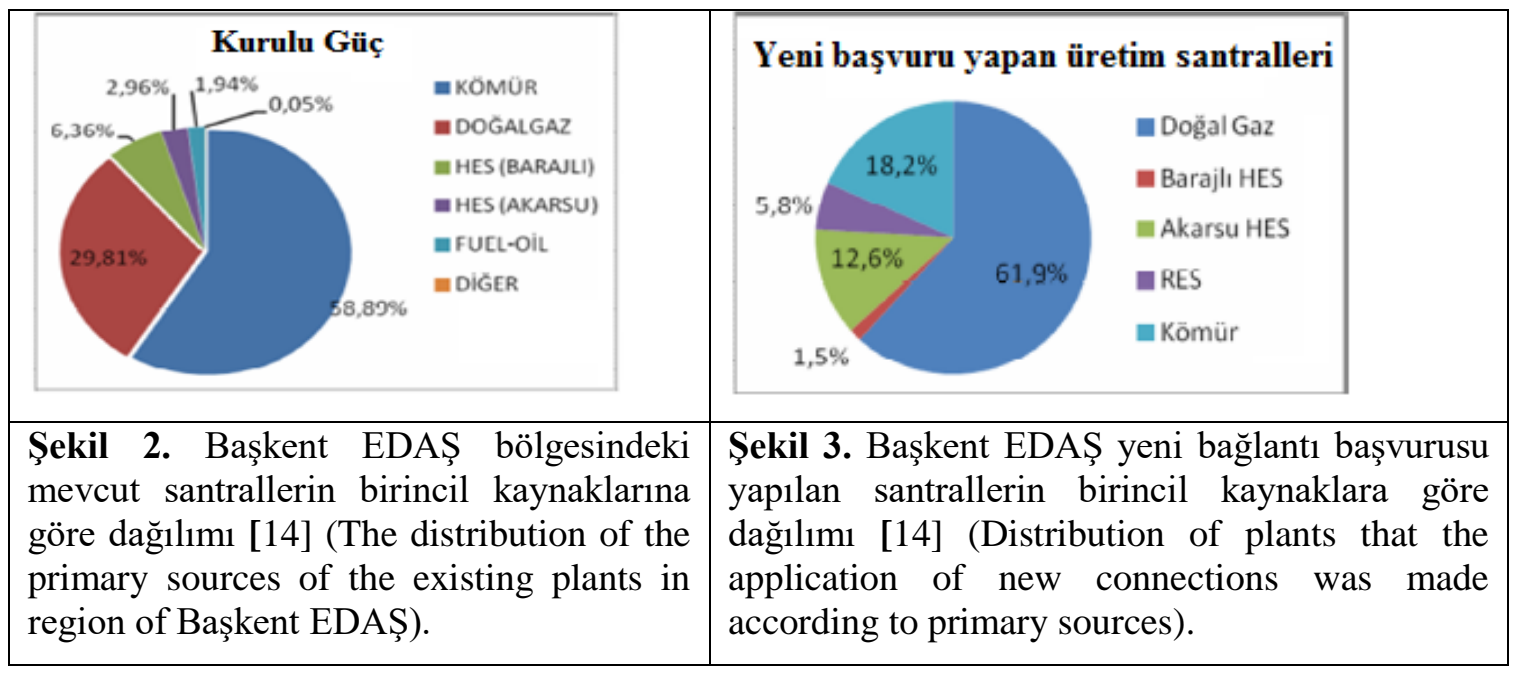

Sonuç olarak, Başkent EDAŞ bölgesi hem mevcut hem de başvuru yapılan santraller açısından değerlendirilecek olursa, kömür ve doğalgaz santrallerinin başını çektiği bir üretim açık olarak ifade edilebilir.

\subsection{Karabük İli Enerji Dengesi (Karabük Province Energy Balance)}

\subsubsection{Karabük'te Fosil Yakıtlar (Fossil Fuels in Karabük)}

Karabük İl sınırları içinde kömür, petrol ve doğalgaz rezervi bulunmamaktadır. Bununla birlikte, petrol ve doğalgaz santrali de yatırımcı tarafından tercih edilmemiştir. Karabük ili, kömürü hem elektrik üretme hem de ısınma amaçlı kullanırken doğal gazı ise elektrik üretme amaçlı değil ısınma, sıcak su ve üretim yapma amaçlı olarak kullanmaktadır. İlde, ilk doğal gaz arzı 2009 yılının Ekim ayında gerçekleşmiştir. Abone sayısı ise 5129'dur. 2011 ylı Ocak ayı doğalgaz tüketim miktarı $4587128 \mathrm{~m}^{3}$ 'tür [15]. Tablo 3'te 2012 ve 2014 yılına ait doğalgaz tüketim miktarları verilmiştir. 
Tablo 3. Karabük ilinin doğalgaz tüketimi [16] (Natural gas consumption of Karabük Province).

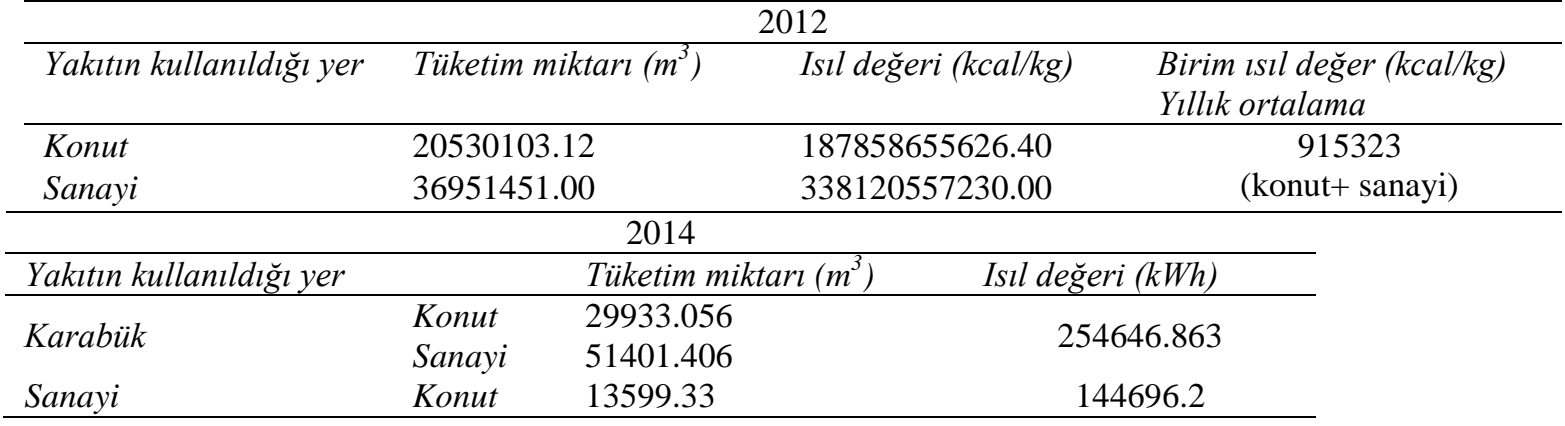

2012 Ekim ayı itibariyle 43350 konuttan sadece 21306 konutta doğal gaz aboneliği bulunmaktadır. 2015 y1lı sonu itibariyle Karabük il merkezi çelik hat uzunluğu 20605 km, PE hatlar 218761 km ve servis hatları $119100 \mathrm{~km}$ olmak üzere toplamda hat uzunluğu $358466 \mathrm{~km}$ 'dir [17]. Diğer illerde olduğu gibi il genelinde doğal gazın kullanılmaya başlanmasıyla hava kirliliğinde önemli bir düşüş gözlenmiş, bununla birlikte 2006 yılından itibaren bir düşüş trendine girdiği de görülmektedir [18]. Karabük ilinde 2014 yılında evsel ısınmada ve sanayide kullanılan katı yakıtların cinsi, yakıtların özellikleri ve bu yakıtların temin edildiği yerler Tablo 4 ve 5 'te verilmiştir.

Tablo 4. Karabük ilinin 2014 yllında evsel ısınmada kullandiğı katı yakıtlar [19] (Solid fuels used in domestic heating of Karabük Province in 2014).

\begin{tabular}{|c|c|c|c|c|c|c|c|}
\hline \multirow[b]{2}{*}{$\begin{array}{l}\text { Yakut } \\
\text { cinsi (*) }\end{array}$} & \multirow[b]{2}{*}{$\begin{array}{l}\text { Temin edilen } \\
\text { yer }\end{array}$} & \multirow[b]{2}{*}{$\begin{array}{l}\text { Tüketim } \\
\text { miktarı } \\
\text { (ton) }\end{array}$} & \multicolumn{5}{|c|}{ Yakıtın özellikleri } \\
\hline & & & $\begin{array}{l}\text { Alt ısll } \\
\text { değeri } \\
(\mathrm{kcal} / \mathrm{kg})\end{array}$ & $\begin{array}{l}\text { Ucucu } \\
\text { madde } \\
(\%)\end{array}$ & $\begin{array}{l}\text { Toplam } \\
\text { kükürt } \\
(\%)\end{array}$ & $\begin{array}{l}\text { Toplam } \\
\text { nem } \\
(\%)\end{array}$ & $\begin{array}{l}\text { Kül } \\
(\%)\end{array}$ \\
\hline Yerli taş kömürü & Zonguldak & 20000 & 7155 & 32.121 & 0.27 & 2.49 & 12.55 \\
\hline İthal kömür & $\begin{array}{l}\text { Rusya, } \\
\text { Mozambik, vb. }\end{array}$ & 50000 & 7789 & 22.87 & 0.28 & 3.88 & 4.08 \\
\hline
\end{tabular}

(*) Yerli kömür, ithal kömür, briket, biyokütle, Sosyal Yardımlaşma Vakfı kömürü, odun gibi

Tablo 5. Karabük ilinin 2014 yllında sanayide kullandiğg katı yakıtlar [20] (Solid fuels used in industry of Karabük Province in 2014).

\begin{tabular}{|c|c|c|c|c|c|c|c|}
\hline \multirow[b]{2}{*}{$\begin{array}{l}\text { Yakit } \\
\operatorname{cinsi}(*)\end{array}$} & \multirow[b]{2}{*}{ Temin edilen yer } & \multirow[b]{2}{*}{$\begin{array}{l}\text { Tüketim } \\
\text { miktarı } \\
\text { (ton) }\end{array}$} & \multicolumn{5}{|c|}{ Yakıtın özellikleri } \\
\hline & & & $\begin{array}{l}\text { Alt } \mathrm{lsll} \\
\text { değgeri } \\
(\mathrm{kcal} / \mathrm{kg})\end{array}$ & $\begin{array}{l}\text { Uçucu } \\
\text { madde } \\
(\%)\end{array}$ & $\begin{array}{l}\text { Toplam } \\
\text { kükürt } \\
(\%)\end{array}$ & $\begin{array}{l}\text { Toplam } \\
\text { nem } \\
(\%)\end{array}$ & $\begin{array}{l}\text { Kül } \\
(\%)\end{array}$ \\
\hline $\begin{array}{l}\text { Koklaşabilir } \\
\text { taşkömürü }\end{array}$ & $\begin{array}{l}\text { Yerli-TTK } \\
\text { Ithal (ABD, Rusya) }\end{array}$ & $\begin{array}{l}302962 \\
951038 \\
\end{array}$ & 7703 & 25.37 & 0.78 & 9.32 & 8.76 \\
\hline Antrasit & İthal (Ukrayna) & 3648 & 7295 & 5.21 & 1.08 & 7.49 & 8.75 \\
\hline Kok tozu & Ithal & 61244 & 6590 & 1.02 & 0.70 & 13.87 & 15.20 \\
\hline $\begin{array}{l}\text { Santral } \\
\text { kömürü }\end{array}$ & $\begin{array}{l}\text { Yerli-TTK } \\
\text { Ithal-Gürcistan }\end{array}$ & $\begin{array}{l}78131 \\
6885\end{array}$ & 6805 & 30.85 & 0.34 & 11.62 & 14.72 \\
\hline Metalürjik kok & Ithal-Rusya & 18.365 & 6927 & 0.62 & 0.69 & 7.19 & 10.86 \\
\hline $\begin{array}{l}\text { Enjeksiyon } \\
\text { kömürü }\end{array}$ & $\begin{array}{l}\text { Ithal (Rusya- } \\
\text { Ukrayna) }\end{array}$ & 80.834 & 6715 & 11.38 & 0.86 & 0.76 & 10.75 \\
\hline
\end{tabular}

(*) Yerli kömür, ithal kömür, briket, biyokütle, Sosyal Yardımlaşma Vakfı kömürü, odun gibi

Karabük'ün 2013 yılı Dış Ticareti; toplam ihracat 199777 bin ABD Doları, toplam ithalat 468351 bin ABD Doları ve dış ticaret dengesi -268574 bin ABD Doları'dır [21]. Buna göre, dış ticaret dengesini negatif yönde bozan bir il konumundadır. Bununla birlikte Türkiye'nin dış ticaret dengesine görece etkisi oldukça sınırlıdır. 


\subsubsection{Karabük’te Jeotermal enerji (Geothermal energy in Karabük)}

Acısu ve Akkaya termal olmak üzere iki jeotermal alan bulunmaktadır. Ancak, bu sahalar kaplica amaçlı kullanılmaya uygun olup enerji üretimi için yeterli şartları sağlayamamaktadır.

\subsubsection{Karabük’te Rüzgar enerjisi (Wind energy in Karabük)}

Türkiye'de, yenilenebilir enerjiye yapılan yatırımların başında RES'ler gelmektedir. 2016 yılı Mart sonu itibariyle RES kapasitesi 4600 MW'tır. Karabük ili için RES kurulabilir alanlar Şekil 4'te verilmiştir. Tablo 6'da ise Karabük iline kurulabilecek RES güç kapasitesi verilmiştir. Rüzgar türbini kurmak için farklı noktalarda ölçümler yapılmasına rağmen an itibariyle Karabük ilinde rüzgara dayalı bir enerji üretimi gerçekleştirilmemektedir.

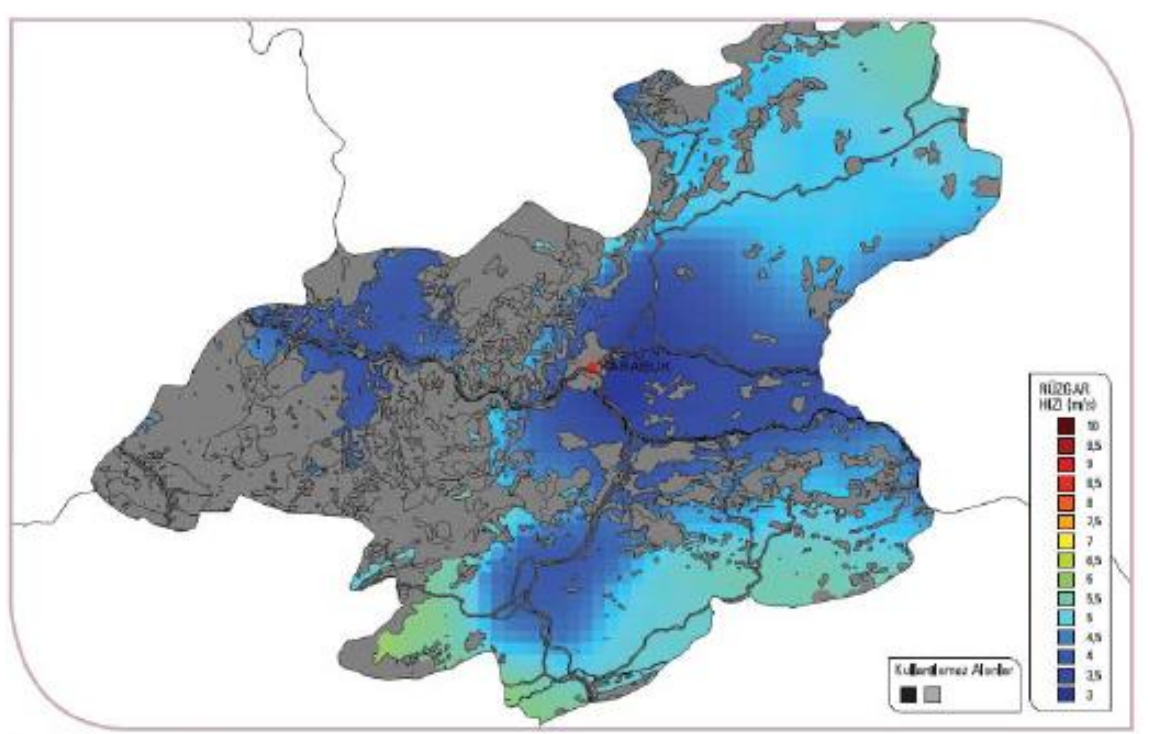

Şekil 4. RES kurulabilir alanlar [22, *Gri renkli alanlara rüzgar santralı kurulamayacă̆ kabul edilmiştir]. (Areas that wind energy can be installed).

Tablo 6. Karabük iline kurulabilecek RES güç kapasitesi [22] (Wind power plant capacity that can be installed in the province of Karabük).

\begin{tabular}{cccc}
\hline 50 m'de rüzgar gücü $\left(\mathrm{W} / \mathrm{m}^{2}\right)$ & 50 m'de Rüzgar hizı $(\mathrm{m} / \mathrm{s})$ & Toplam alan $\left(\mathrm{km}^{2}\right)$ & Toplam kurulu güç $(\mathrm{MW})$ \\
\hline $300-400$ & $6.8-7.5$ & 14.67 & 73.36 \\
$400-500$ & $7.5-8.1$ & 0.0 & 0.0 \\
$500-600$ & $8.1-8.6$ & 0.0 & 0.0 \\
$600-800$ & $8.6-9.5$ & 0.0 & 0.0 \\
$>800$ & $>9.5$ & 0.0 & 0.0 \\
\hline & Toplam & 14.67 & 73.36
\end{tabular}

\subsubsection{Karabük’te Güneș enerjisi (Solar energy in Karabük)}

Her geçen gün PV panel fiyatları düşerken buna karşın verimlilikleri de artmaktadır. 2016 Şubat ayı itibariyle modül verimliliği \% 22.8'e çıkmıştır. Bu bağlamda, verimlilik arttıkça dünya genelinde güneşe olan yatırım da artarak devam edecektir. Türkiye güneş enerjisi santrali (GES) kurulu gücü 2014 y1lsonu itibariyle 40 MW iken 2015'te 248.8 MW'a ulaşmıştır. Santral sayısı 112'den 454'e ve 
katk1 \% 0.1'den \% 0.4'e yükselmiştir. 2016 yılı Mart sonu itibariyle 492 adet santral ile GES kapasitesi 357.7 MW'a ulaşmış olup katkı oranı \% 0.5'tir. Karabük ilinde ise kurulu güç 0.67 MW'tır. Özel bir şirkete ait bir alışveriş merkezinin çatısında 12 bin $\mathrm{m}^{2}$ lik alanda 2804 adetten oluşan PV santrali ile 150 bin $\mathrm{kWh}$ elektrik üretilmekte ve 50 bin kWh'i iç tüketimde kullanılmaktadır. Şekil 5, 6 ve 7'de sırasıyla Karabük iline ait güneş haritası, Karabük iline ait güneş verileri ve Karabük iline ait PV tipi-alan-üretilebilecek enerji değerleri gösterilmiştir.

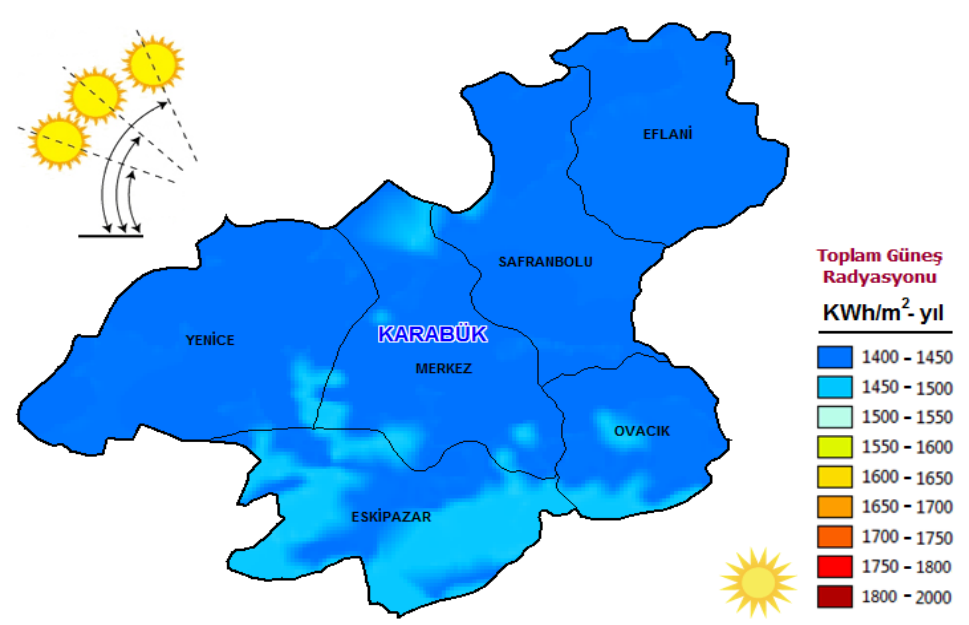

Şekil 5. Karabük iline ait güneş haritası [23] (Solar map of the Karabük province).

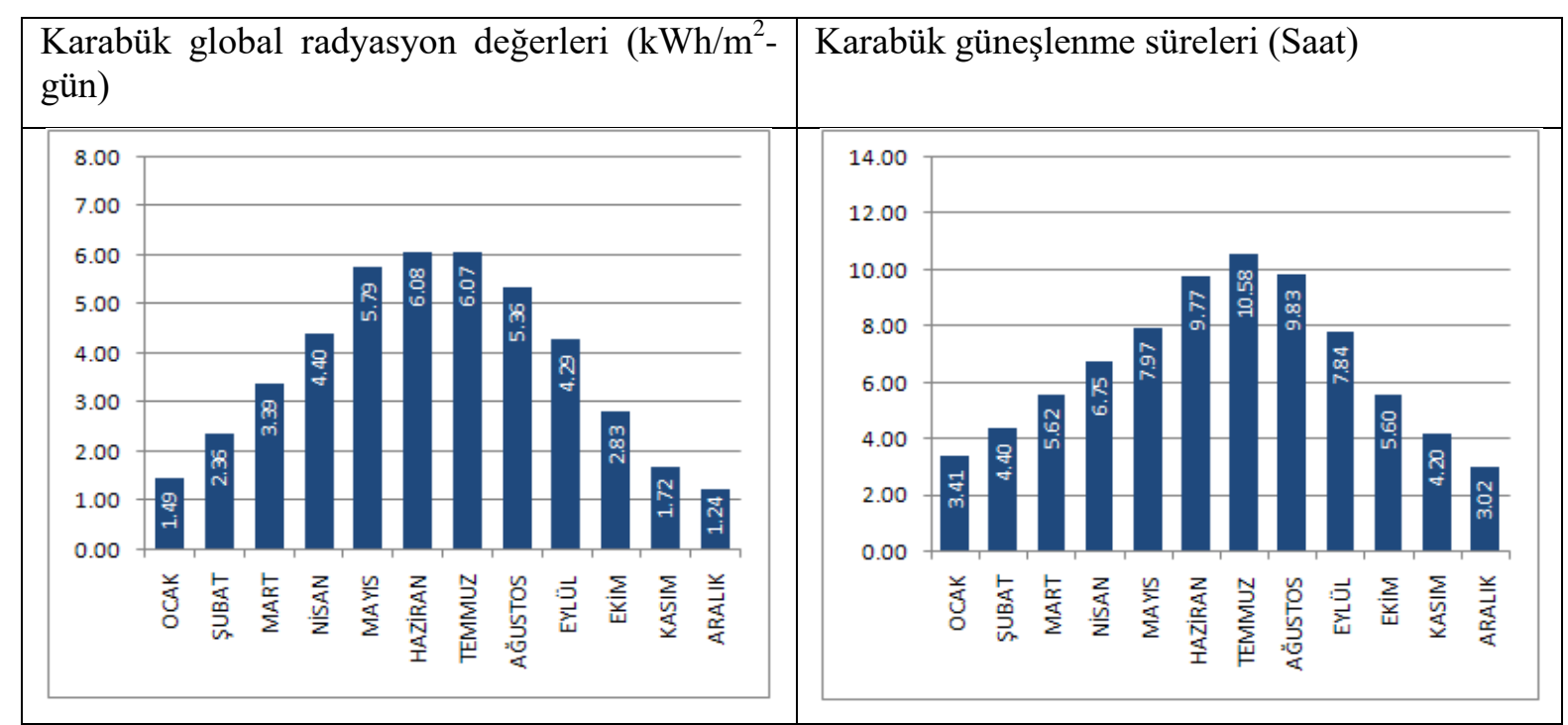

Şekil 6. Karabük iline ait güneş verileri [23] (Solar data of the Karabük province).

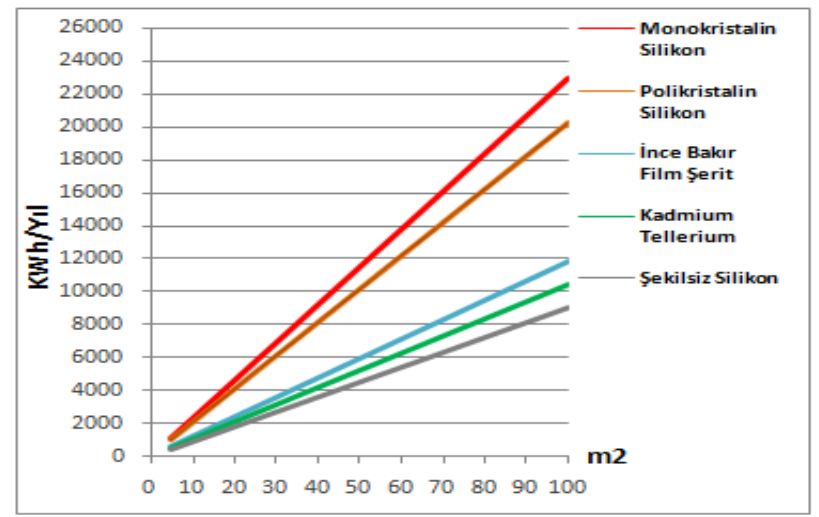


Şekil 7. Karabük PV tipi-alan-üretilebilecek enerji (kWh-yıl) [23] (PV type-field-energy that can be produced in Karabük, $k$ Wh-year)

İl genelinde sicak su hazırlama amaçlı olarak düz ve vakumlu tip güneş enerjisi sistemleri kullanılmaktadır. İl genelinde $k a c ̧ \mathrm{~m}^{2}$ güneş kolektörü olduğu bilgisi mevcut değildir.

\subsubsection{Karabük İli Elektrik Üretimi ve Tüketimi (Electricity Generation and Consumption of Karabük Province)}

Karabük'ün elektrik enerjisi kurulu gücü 122 MW'tır. 4 adet lisanslı ve 1 adet lisanssız olmak üzere toplamda 5 adet aktif elektrik enerji santrali ile yıllık yaklaşık $530 \mathrm{GW}$ elektrik üretimi yapılmaktadır. Karabük’teki mevcut elektrik santrallerinin kaynaklara göre kurulu güç dağılımı Tablo 7'de, işletme halinde olan elektrik santralleri ise Tablo 8'de verilmiştir. Buna göre, HES ve Kömür ağırlıklı bir elektrik üretimi söz konusudur. Kurulu gücün ortalama üretim kapasitesi aylık 44.16 GWh ve günlük $1.45 \mathrm{GWh}$ dolayındadır. Karabük'ün Türkiye kurulu gücüne oranı \% 0.17 iken Türkiye tüketimine oranı \% 0.21 'dir. Karabük'teki lisanslı ve lisanssız santraller sirasılyla Tablo 9 ve 10 'da verilmiştir. Tablolara göre, Karabük toplam lisanslı santral kurulu gücü 281.73 MWe ve lisanssiz toplam kurulu güç 1.04 MW'tır.

Tablo 7. Karabük'teki elektrik santralleri dağılımı. (The distribution of electric power plants in Karabük).

\begin{tabular}{ll}
\hline Tipi & Kurulu güç $(M W)$ \\
\hline Güneş & 0.67 \\
HES & 70.93 \\
Kömür & 50 \\
\hline
\end{tabular}

Tablo 8. İsletmedeki elektrik santralleri (Power plants in operation).

\begin{tabular}{lllll}
\hline No & Santral adı & Tesis türü & Firma & Kurulu güç $(M W)$ \\
\hline 1 & Kardemir Karabük DÇ Termik Santrali & Kömür & Kardemir A.Ş. & 50 \\
2 & Eren Reg. ve HES & HES & Akbaş Holding Enerji Grubu 35 \\
3 & Pirinçlik HES & HES & Kardemir A.Ş. & 21 \\
4 & Yalnızca HES & HES & Rönesans Enerji & 14 \\
5 & Tema Trend Gayrimenkul GES & GES & Tema Trend Gayrimenkul & 0.67 \\
& & Yapım aşamasında olan santraller & \\
1 & Şimşir Reg. ve HES & HES & & 4.6 \\
\hline
\end{tabular}


Tablo 9. Karabük'teki lisansl santraller [24] (Licensed plants in Karabük).

\begin{tabular}{|c|c|c|c|c|c|c|c|c|c|}
\hline & Unvan & $\begin{array}{l}\text { Başlangıç/ } \\
\text { yürürlük } \\
\text { tarihi }\end{array}$ & $\begin{array}{l}\text { Bitis } \\
\text { tarihi }\end{array}$ & $\begin{array}{l}\text { Tesis } \\
\text { türü }\end{array}$ & Tesis adl & $\begin{array}{l}K G \\
(M W m)\end{array}$ & $\begin{array}{l}K G \\
(M W e)\end{array}$ & $\begin{array}{l}\dot{I} h K \\
(M W e)\end{array}$ & $\begin{array}{l}\dot{I} K \\
(M W e)\end{array}$ \\
\hline \multirow{9}{*}{ 辛 } & ELİTE & 12.04 .2007 & 12.04 .2056 & HES & Han HES & 6.14 & 5.53 & 5.53 & 0 \\
\hline & AKSU & 16.05 .2006 & 16.05 .2055 & HES & Tefen HES & 36.75 & 33 & 0 & 33 \\
\hline & FİLYOS & 23.12 .2005 & 23.12 .2045 & HES & Yalnızca HES & 4.36 & 4.32 & 0 & 4.32 \\
\hline & T.M. & 15.01 .2009 & 15.01 .2058 & HES & $\begin{array}{l}\text { Şimşir Reg. ve HES } \\
\text { Pirinçlik Reg. ve }\end{array}$ & 4.9 & 4.6 & 4.6 & 0 \\
\hline & ENBATI & 29.01 .2009 & 29.01 .2058 & HES & HES & 22.194 & 21.315 & 21.315 & 0 \\
\hline & IRMAK & 25.12 .2008 & 25.12 .2057 & HES & Eren HES & 37.038 & 35.184 & 35.184 & 0 \\
\hline & İFLAS HAL. & 25.06.2009 & 08.06.2056 & HES & Suçatı HES & 44.343 & 42.999 & 42.999 & 0 \\
\hline & ORSA & 20.10 .2011 & 20.10 .2060 & RES & Fener & 6 & 5 & 5 & 0 \\
\hline & KARDEMIR & 01.05 .2014 & 02.10 .2018 & Termik & Karabük & 89.42 & 87.5 & 65 & 22.5 \\
\hline \multirow{5}{*}{ 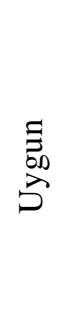 } & S.H. & & & HES & $\begin{array}{l}\text { Uzunburun Reg. ve } \\
\text { HES } \\
\text { Alaboğa Reg. ve }\end{array}$ & 13.8 & 13.45 & 13.45 & 0 \\
\hline & S.H. & & & HES & HES & 4.73 & 4.63 & 4.63 & 0 \\
\hline & BBS & & & HES & Yenice Reg. ve HES & 7 & 6.72 & 6.72 & 0 \\
\hline & FÍLYOS & & & HES & $\begin{array}{l}\text { Doğan HES } \\
\text { Kadıbükü Reg. ve }\end{array}$ & 8.55 & 8.25 & 8.25 & 0 \\
\hline & BATU & & & HES & HES & 9.609 & 9.228 & 9.228 & 0 \\
\hline
\end{tabular}

Tablo 10. Karabük lisanssız santraller [25] (Unlicensed plants in Karabük).

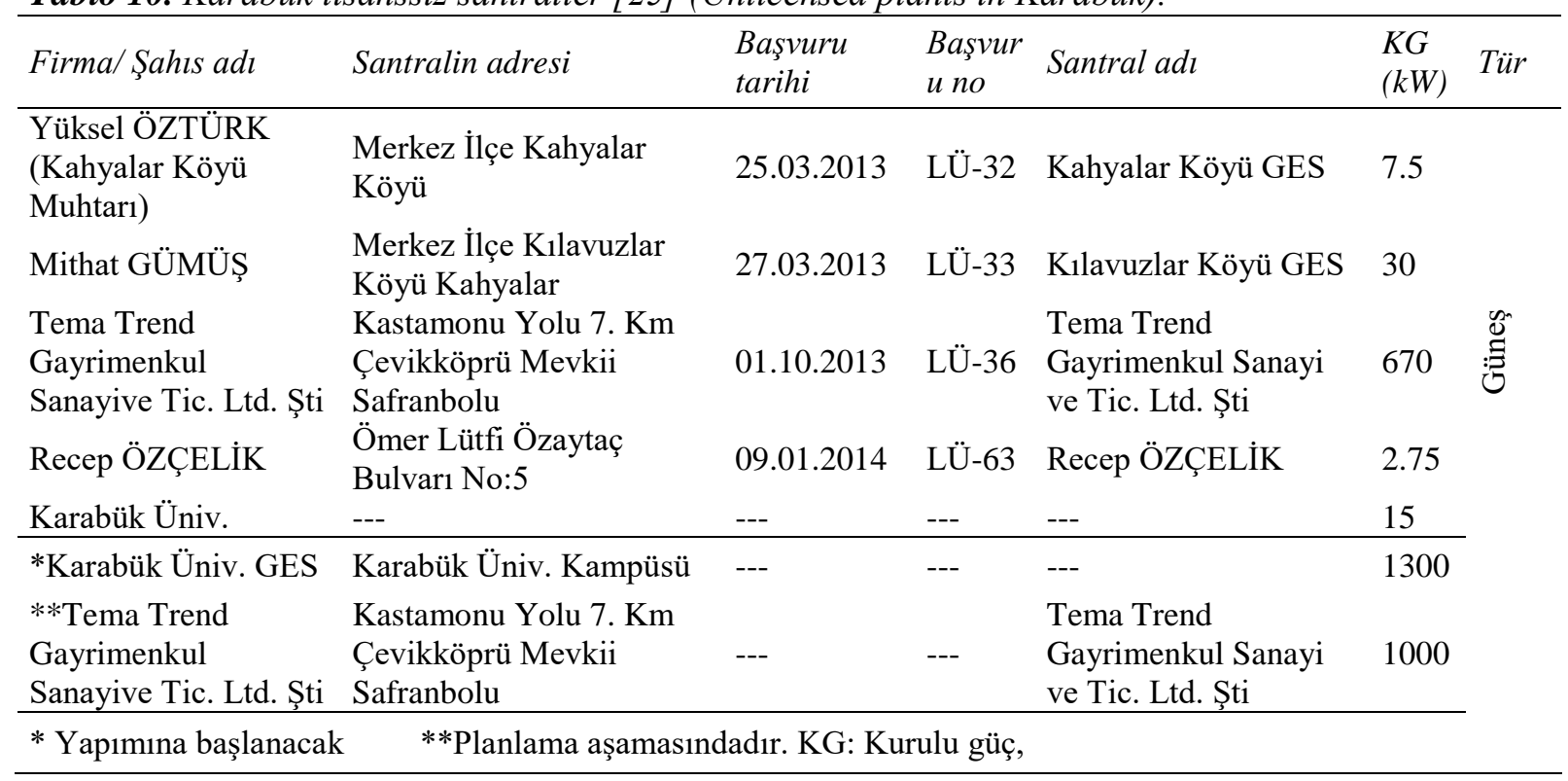

Tablo 11'de Karabük'teki tüm HES'lere ait enerji verileri gösterilmiştir. Tabloya göre, Karabük'te işletmede olan ve işletmeye alınması planlanan bütün santrallerin toplam kurulu güç miktarı 237.7 MW'dır. Bu santrallerin yıllık toplam enerji üretimi ise 713.7 GWh olacaktır [26]. Karabük, ilçelerinde bulunan Soğanl,, İncedere, Banaz, Karakaya gibi akarsu zenginliklerine sahiptir. Karabük'teki HES'lerin büyük bir çoğunluğu fizibilite aşamasında olup sadece 3 adedi devrede iken 1 adedi yapım aşamasındadır. 
Tablo 11. Karabük'te tüm HES'lere ait enerji verileri [26, *Veriler klsmen güncellenmiştir] (Energy data for Hydraulic Power Plants in Karabük).

\begin{tabular}{|l|l|l|l|}
\hline Projenin adl & Akarsu & $\begin{array}{l}\text { Kurulu gü̧̧ } \\
(M W)\end{array}$ & $\begin{array}{l}\text { Toplam enerji } \\
(\text { GWh })\end{array}$ \\
\hline Yalnızca HES & & 15.3 & 56.88 \\
\hline Eren HES & & $55.68^{*}$ & 141.898 \\
\hline Pirinçlik HES & & $23.92^{*}$ & 76.85 \\
\hline Kadıbükü HES & Filyos/Araç & 8.27 & 26.36 \\
\hline Filyos HES & Filyos/Yenice & 10.4 & 53.6 \\
\hline Aktaş HES & Soğanl/Filyos/Yenice & 12.5 & 37.74 \\
\hline İkiler HES & Soğanl//Gerde/Filyos/Yenice & 3.3 & 11.38 \\
\hline Karakaya HES & Karakaya/Filyos/Yenice & 4.6 & 14.27 \\
\hline Şimşir HES & Şimşir/Filyos/Yenice & 4.9 & 15.75 \\
\hline Suçatı HES & Filyos/Yenice & 32.5 & 85.34 \\
\hline Han Reg. ve HES & Filyos/Yenice/Araç/Eflani & 6.14 & 16.21 \\
\hline Suçatı II HES & Filyos/Yenice & 10.5 & 24.36 \\
\hline Doğan HES & Soğanl//Filyos & 29.07 \\
\hline $\begin{array}{l}\text { Eskipazar Çayı Çalkaya Reg. ve } \\
\text { Cemal Ovası HES }\end{array}$ & Soğanl1/Filyos/Yenice/Eskipazar & 10 & 29.5 \\
\hline Alac1kgüney Reg. ve HES & & & \\
\hline Alaboğa Reg. ve HES & Soğanl//Filyos/Yenice/ Eskipazar & 0.7 & 3.6 \\
\hline Alel 5 Reg. ve HES & İncedere/Filyos/Yenice & 4.73 & 18.41 \\
\hline Çatacık HES & İncedere/Filyos/Yenice & 2.84 & 7.75 \\
\hline Yenice HES & Banaz/Filyos/Yenice/Eskipazar & 1.15 & 4.81 \\
\hline Mağara Reg. ve HES & Simşir/Filyos/Yenice & 7 & 21.54 \\
\hline Uzunburun HES & Buldan/Filyos/Yenice/Araç & 1.24 & 6.3 \\
\hline * EPDK & İncedere/Filyos/Yenice & 13.45 & 32.084 \\
\hline
\end{tabular}

2012 yılı için bazı illerin kişi başına toplam elektrik tüketimi Şekil 8'de verilmiştir. 2012 yılında Karabük ilinin kişi başına toplam elektrik tüketimi 4416 kWh iken 2013 yılında 4618 kWh olarak gerçekleşmiştir [27]. Bu değerler, Türkiye ortalaması olan $2577 \mathrm{kWh}$ değerinin üzerindedir.

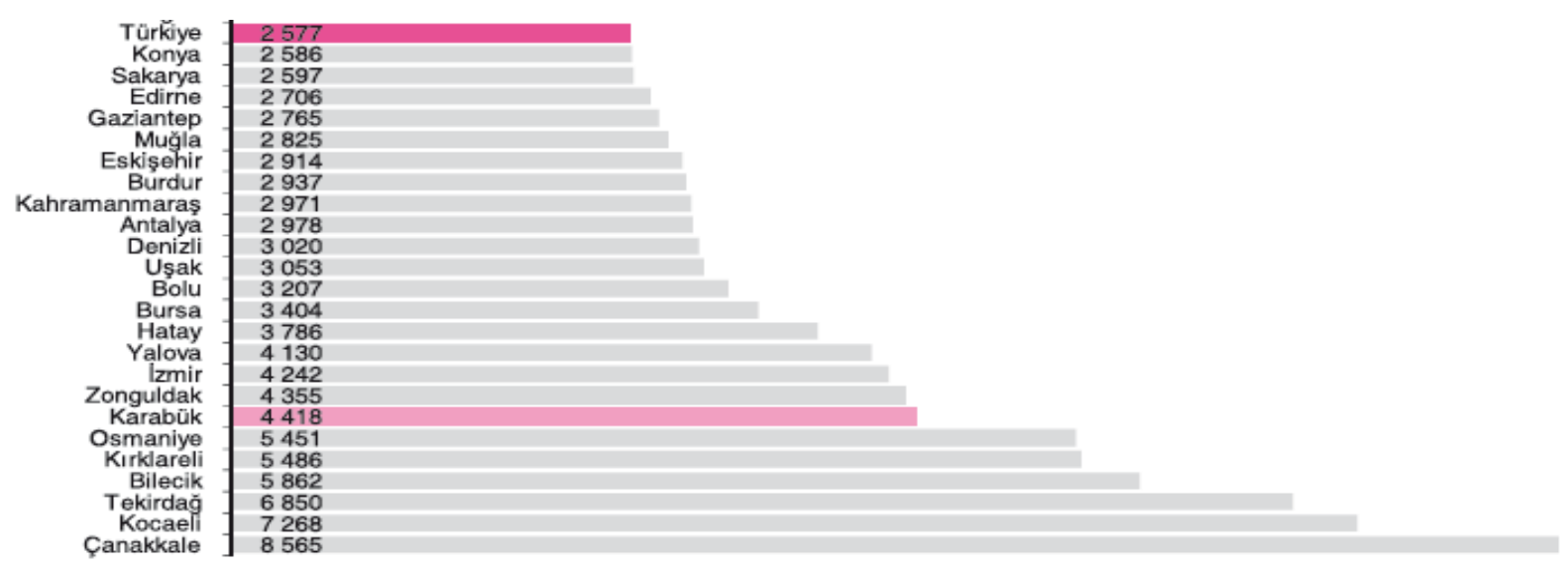

Şekil 8. 2012 yll kişi başına toplam elektrik tüketimi (kWh) (Total electricity consumption per person in 2012, $\mathrm{kWh}$ ).

2008-2012 yılları arasında kullanım yerlerine göre elektrik tüketimi Tablo 12'de, tüketici sayıları ve tüketimleri Tablo 13'te ve dağıtım tesisi bilgileri ise Tablo 14'te verilmiştir. 
Tablo 12. Kullanım yerlerine göre 2008-2012 Karabük elektrik tüketim değerleri (MWh) [27]

(Karabük electricity consumption values in 2008-2012 years).

\begin{tabular}{lllllllll}
\hline Y1llar & $\begin{array}{l}\text { Toplam } \\
\text { tüketim }\end{array}$ & $\begin{array}{l}\text { Resmi } \\
\text { daire }\end{array}$ & Sanayi & Ticarethane & Mesken & $\begin{array}{l}\text { Tarımsal } \\
\text { sulama }\end{array}$ & $\begin{array}{l}\text { Sokak } \\
\text { aydınlatma }\end{array}$ & Diğer \\
\hline 2008 & 732298 & 17551 & 507693 & 40120 & 143883 & 453 & 17204 & 5394 \\
2009 & 745085 & 14198 & 546199 & 43057 & 109224 & 454 & 18196 & 13746 \\
2010 & 774472 & 16071 & 566018 & 46637 & 114933 & 472 & 18349 & 9991 \\
2011 & 881337 & 15214 & 662933 & 49174 & 124066 & 905 & 19601 & 9444 \\
2012 & 994753 & 25956 & 759227 & 66616 & 119580 & 733 & 18946 & 3695 \\
\hline
\end{tabular}

Not: 1) Şantiye tüketimleri sanayi içerisinde yer almaktadır.

2) Yuvarlamalar nedeniyle toplamlar farklı olabilir.

Tablo 13. Dăğtım seviyesinden bağlı tüketicilerin sayısı ve tüketimleri [28] (Number of consumers depends on the distribution level and their consumptions).

\begin{tabular}{|c|c|c|c|c|}
\hline \multirow{3}{*}{ Tüketici sektörü } & \multicolumn{4}{|c|}{ Dağıtım Seviyesinden Bă̆lı Tüketicilerin Sayısı ve Tüketimleri } \\
\hline & \multicolumn{2}{|c|}{ Tüketici sayısı (Adet)* } & \multicolumn{2}{|c|}{ Tüketim miktarl $(M W h) * *$} \\
\hline & Abone & Serbest tüketici & Abone & Serbest tüketici \\
\hline Aydınlatma & 2.159 & 1 & 936 & 46 \\
\hline Mesken & 112.270 & 741 & 9.143 & 267 \\
\hline Sanayi & 165 & 19 & 15.281 & 1.160 \\
\hline Tarımsal sulama & 1.466 & - & 58 & - \\
\hline Ticarethane & 13.049 & 2.748 & 3.897 & 7.253 \\
\hline
\end{tabular}

* 2015 yılı Ocak ayı sonu itibariyle dağıtım seviyesinden sisteme bağlı tüketicilerin sayısıdır.

** 2015 yılı Ocak ayı verileri esas alınmıştır. Dağıtım seviyesinden sisteme bağlı tüketicilerin tüketimidir.

Tablo 14. Dă̆gtım tesisi bilgileri [28] (Information of distribution facility).

\begin{tabular}{|c|c|c|c|c|}
\hline Mülkiyet & $\begin{array}{l}\text { Gerilim } \\
\text { seviyesi }\end{array}$ & $\begin{array}{l}\text { Mevcut hat uzunluğu } \\
\text { (Km) }\end{array}$ & $\begin{array}{c}\text { Mevcut trafo kapasitesi } \\
\text { (Kurulu güç MVA) }\end{array}$ & $\begin{array}{l}\text { Mevcut trafo } \\
\text { saylsl (Adet) }\end{array}$ \\
\hline \multirow{2}{*}{ Kurum* } & $A G$ & 2.304 & 201 & 1.139 \\
\hline & $O G$ & 1.836 & 59 & 7 \\
\hline \multirow{2}{*}{$\ddot{O}_{z e l}{ }^{*}$} & $A G$ & 7 & 120 & 243 \\
\hline & $O G$ & 5 & 25 & 1 \\
\hline \multicolumn{5}{|c|}{ *31.12.2014 itibariyle } \\
\hline \multirow{3}{*}{$\begin{array}{c}\text { Mevcut hat } \\
\text { uzunluğu }(\mathrm{Km})\end{array}$} & Havai & 3.735 & & \\
\hline & Yeraltı & 405 & & \\
\hline & Diğger & 12 & & \\
\hline \multirow{3}{*}{$\begin{array}{c}\text { Dağıtım yatırım } \\
\text { miktarı (TL) }\end{array}$} & Yeni trafo & 2.276 .981 & & \\
\hline & Yeni hat & 2.725 .683 & & \\
\hline & Diğer & 2.159 .161 & & \\
\hline
\end{tabular}

\subsubsection{Enerji Akış Şeması (Energy Flowchart)}

Enerji dengesini ifade etmek için enerji akış şemaları kullanılır. Enerji akış şemaları olarak adlandırılan ve enerji kaynaklarını ve onların nihai kullanımını gösteren bu diyagramlar, bilim adamları, analistler ve diğer karar vericiler için karmaşı ilişkileri görselleştirir. Enerji akış şemaları; artıları, eksileri ve temel belirsizlikleri tespit etmek için önemli bir göstergedir. Bununla birlikte asıl mesele, belirsizlikleri oluşturan nedenleri anlamak ve çözüm üretmektir. Bu noktada, yatırımcılar ve politika yapıcılar hatta son kullanıcı önemli rol oynamaktadır. ABD Utah eyaleti için hazırlanan enerji akış kartından yararlanılarak Karabük için bir enerji akış şeması oluşturulmuştur (Şekil 9). 
Ancak Karabük'e ait bazı güncel verilere ulaşılamadığından bazı alanlar yeterli rakamsal veri ile desteklenememiştir. Bununla birlikte farklı resmi veya resmi olmayan enerji veri kaynakları ile çalışılmış bu nedenle istatistiksel farklılık oluşmuş olabilir. Karabük ilinin mevcut enerji arz-talep dengesinin ana özellikleri sayısal ve görsel olarak diyagramdan görülebilir. Kömür, hidrolik ve petrol ana kaynaklar olarak görünmektedir. Tüketilen kömürün büyük kısmı ithaldir buna karşın bir kısmı yerli olmakla beraber il genelinde üretilmeyip il dışından alınmaktadır.

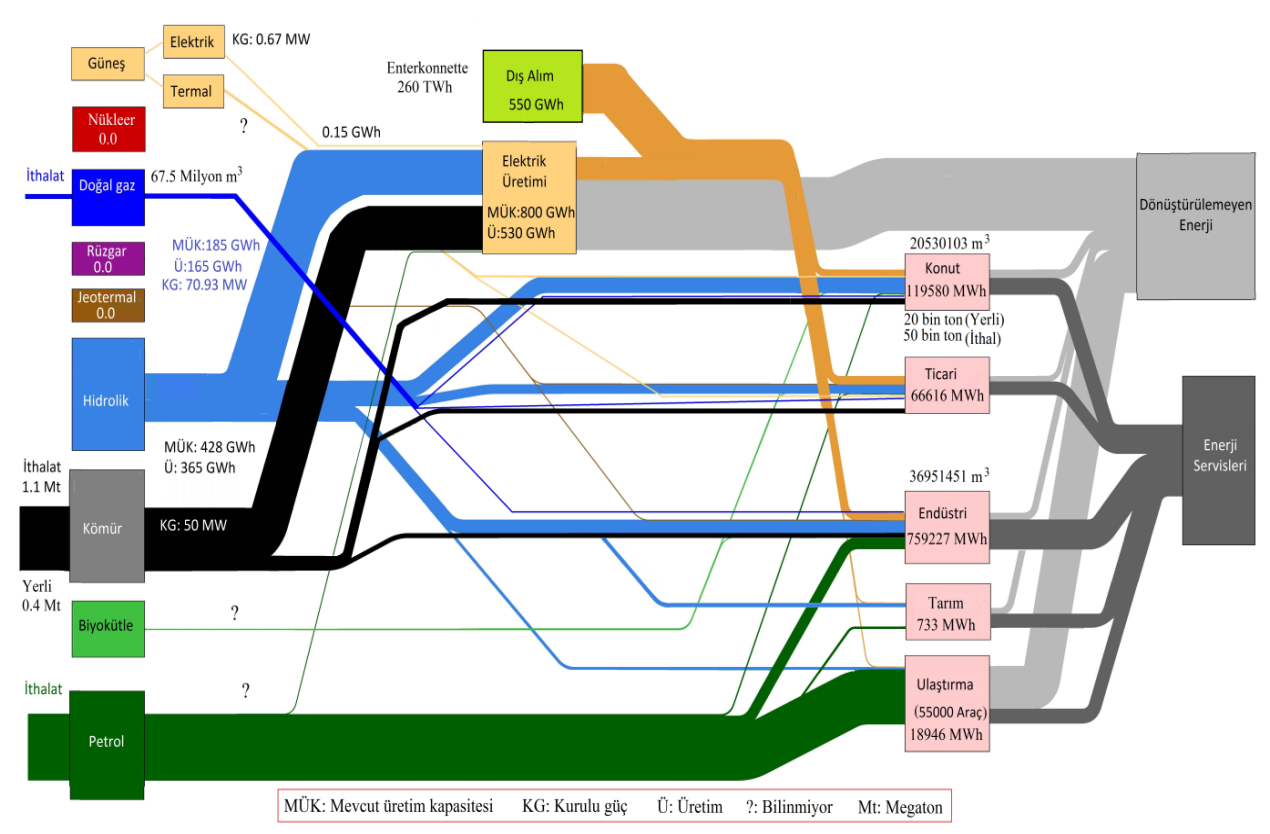

Şekil 9. Karabük ili enerji akış şeması (Energy flowchart of Karabük Province).

\section{SONUÇLAR VE ÖNERILER (Results And Suggestions)}

Bu çalışmada, Karabük ili için enerji dengesi incelenmiş ve enerji akış şeması oluşturulmuştur. $\mathrm{Bu}$ çalışma, Karabük'ün enerji alanındaki potansiyelini ortaya koymakta ve sürdürülebilirliğin sağlanmasındaki mevcut rolüne bakış açısı sunmaktadır.

- Kömür hem elektrik üretiminde hem de konut ihtiyaçlarında, doğalgaz ise elektrik üretimi dışındaki alanlarda kullanılmaktadır. Petrolün büyük bir kısmı ulaştırmada kullanılmaktadır.

- Karabük'te elektrik üretimi kömür ve hidrolik ağırlıklıdır.

- Karabük ilinde elektrik tüketiminin büyük bir bölümünü endüstride, enerji yoğun bir sektör olan demir-çelik endüstrisinde, gerçekleşmektedir.

- Kardemir A.Ş., bünyesinde barındırdığı 50 MW'lık kömür kaynaklı bir elektrik santralinden elektrik tüketimini karşılamaktadır. Bununla birlikte bu sektör içerisinde yer alan pek çok küçük ve orta boyuttaki işletmeler de yoğun bir şekilde enerji tüketmektedirler.

- Yenilenebilir enerjinin toplam kurulu güç içerisinde payı \% 58.8 iken toplam enerji üretimi içerisindeki payı ise \% 32'dir.

- 2020 yılına kadar elektrik üretimine yaklaşık 2.3 MW güneş ve 50 MW hidrolik kapasite eklenmesi beklenmektedir.

- Üretim-tüketim oranları, planlanan ve lisans almış yatırımlar, il genelindeki kaynaklar düşünüldüğünde ve üstüne üstlük enerji tüketiminin sürekli arttığı günümüzde Karabük ili için üretimin tüm tüketimi karşılaması mümkün görülmemektedir. 
İl bazında enerji analizi ülkenin enerji sorunlarını çözmede yardımcı olabilir. Bu bağlamda genel ve il bazında, yerinde üretim ve dağıtık üretime yönelmek enerjinin verimli yönetilmesine katkı sağlayabilir.

\section{KAYNAKLAR (REFERENCES)}

[1]. Bayrak, Y. “Ankara ili elektrik üretim-tüketim durumu”, İÇEF-Ankara Enerji Forumu, Ankara, 24-25 Şubat 2007.

[2]. Yang, Y., Sun, X., Zhu, X., Xie, Y. "Scenario simulation and policy analysis on energy development in Qinghai Province”, Procedia Computer Science, 17, 720-28, 2013.

[3]. Mischke, P., Xiong, W. "Mapping the energy flow from supply to end use in three geographic regions of China", 4th Asian Energy Economics Conference, Beijing, Armenia, 2014.

[4]. Bastianoni, S., Marchettini, N., Panzieri, M., Ridolfi, R. "Thermodynamic analysis of the province of Ravenna (Italy)", Ann Chim., 92(9), 771-81, 2002.

[5]. Liu, H., Wang, Q., Li, XJ., Song, Y., Li, GJ. "Emergy analysis of ecological-economic system in Liaoning Province", Chinese Journal of Applied Ecology, 19(3), 627-33, 2008.

[6]. EMO, "İstanbul ili elektrik üretim-tüketim durumu", www.emo.org.tr/ekler/64c47f97ee545d0_ek.pdf, [Erişim: 05.01.2016].

[7]. Simon, AJ., Belles, RD. "Estimated State-level energy flows in 2008", Lawrence Livermore National Lab., United States, January 2011, https://flowcharts.llnl.gov/content/energy/energy_archive/energy_flow_2008/2008StateEnergy. pdf.

[8]. Lawrence Livermore Ulusal Laboratuarı (LLNL), http://lowchars.llnl.gov. [Erişim: 07.01.2016].

[9]. Zhang, M., Wang, W. "Using an energy flow chart to analyze Jiangsu Province's energy balance", Renewable Energy, 39, 307-12, 2012.

[10].Cheng, B., Dai, H., Wang, P., Xie, Y., Chen, L., Zhao, D., Masui, T. "Impacts of low-carbon power policy on carbon mitigation in Guangdong Province, China", Energy Policy, 88, 515-27, 2016.

[11]. GÜNDER. http://gunder.org.tr/.

[12]. TEİAŞ, http://www.teias.gov.tr/YukTevziRaporlari.aspx.

[13]. http://www.enerjiatlasi.com. [Erişim: 05.02.2016].

[14]. TEİAŞ, "Üretim tesisleri bölgesel bağlantı kapasite raporu”, 2019-2024, 11.08.2014.

[15]. http://www2.epdk.org.tr/data/DPDVerileri/KARAB\%C3\%9CK.pdf, [Erişim: 20.12.2015].

[16]. KARGAZ, 2015. www.kargaz.com.tr/.

[17]. http://www.kargaz.com.tr/DogalGazYatirim.aspx?SayfaIcerik=51, [Erişim: 20.02.2016].

[18].Yıldız, A., Çay, Y., Özer, F. "Karabük ilindeki hava kirliliğinin doğal gaz kullanımı ile değişimi”, Tarih Kültür ve Sanat Araştırmaları Dergisi, 1(4), 497-506, December 2012.

[19]. Solmaz, G., Budak, E., Karakaş, İ. "Karabük İli 2014 yılı çevre durum raporu”, Karabük Çevre ve Şehircilik İl Müdürlüğü, Karabük, 2015.

[20]. Kardemir A.Ş. Genel Müdürlüğü, 2015, https://www.kardemir.com/.

[21]. TÜIKK, “İllere Göre Dış Ticaret İstatistikleri”, http://www.tuik.gov.tr/PreTablo.do?alt_id=1046, [Erişim: 20.02.2016].

[22]. http://www.eie.gov.tr/YEKrepa/KARABUK-REPA.pdf. 
[23]. http://www.eie.gov.tr/MyCalculator/pages/78.aspx.

[24].http://lisans.epdk.org.tr/epvysweb/faces/pages/lisans/elektrikUretim/elektrikUretimOzetSorgula. xhtml, [Erişim: 04.10.2015].

[25]. www.epdk.org.tr, [Erişim: 04.10.2015].

[26]. Baş, Ş. "Hidroelektrik Enerji, TR81 Bölgesi HES Raporu", T.C. Batı Karadeniz Kalkınma Ajansı (BAKKA), 24-29, 2014.

[27]. TÜİK, "Seçilmiş Göstergelerle Karabük”, 2013, http://www.tuik.gov.tr.

[28]. ww3.epdk.org.tr/documents/.../Str_illerbaz2015OcakElektrikVerileri.xlsx,[Erişim:04.11.2015]. 